\title{
Optimization of Productivity Measures to Improve Performance of Selected Banks - Indian Perspective
}

\author{
P. Sumalatha
}

\begin{abstract}
Efficiency or productivity is one of the significant estimates which help in measuring the development and advancement of economy of the nation. The efficiency has a pivotal influence in authoritative accomplishment of greatness which is basic for dynamic culture. Ideal efficiency of an organization relies upon coordination between all data sources that yield most extreme gainfulness with least exertion. Thus the present research is centre around a goal of recognize and look at the components impacting the efficiency just as benefit execution of selected banks in India both in public and private sector. For which a sample of twenty banks were selected. The time frame considered for the research is ten years from 2008 to 2018. The procedure which is utilized in the present research is correlation analysis which explains the connection between the selected factors. Regression analysis is also utilized to dissect the effect of selected independent factors, for example, magnitude of sales, value addition, cost of sales, profit before tax (PBT) of each worker. Dependent factors encompass of return on assets and return on value addition by fixed assets. Furthermore, free example test is utilized to survey the connection among profitability and execution proportions of selected banks in India both in public and private sector. In this manner, the outcomes from correlation analysis demonstrate that practically all the independent factors aside except from sales volume and cost of sales in selected banks in India both in public and private sector. Results from regression analysis shows that business per worker is having noteworthy negative effect on ROA.
\end{abstract}

Key Words: Efficiency measures, Return on Assets, Cost of Sales, Regression Analysis, Banks in Public and private sector.

\section{INTRODUCTION}

The financial framework assumes a significant job to the monetary advancement of an economy and in development of the nation. Development in operational efficiency of banks has a made them to focus on various societal needs which results in development of infrastructure and basic amenities, which is a sign of growing economy. Money plays as an impetus to the improvement of the nation's economy. There is need to meet the development in finance area and required to make stronger the banks efficiency and their presentation. Banking exercises and its presentation hold the consideration in a country's economy.

Revised Manuscript Received on December 30, 2019.

* Correspondence Author

P. Sumalatha, Asst. Professor in Finace, Dr. BR Ambedkar Institute of Management and Technology, Hyderabad-44

(C) The Authors. Published by Blue Eyes Intelligence Engineering and Sciences Publication (BEIESP). This is an open access article under the CC BY-NC-ND license (http://creativecommons.org/licenses/by-nc-nd/4.0/)
For the financial advancement of a nation, the role of banks is unavoidable and without their contribution one cannot imagine. More spotlights have been put on monetary foundations particularly on business banks in examining both efficiency and execution from the last five decades. Along these lines, keeping in see the significance of banking area changes, the present research expected to dissect the relative variables influencing both efficiency and profitability execution of selected banks in India both in public and private sector. It also focuses on an investigation of banks efficiency utilizing the proportions of sales per worker, value addition by each worker, profit before tax, works cost of each worker, performance estimates like ROA, return on value and worth included per fixed resources.

\section{LITERATURE REVIEW}

Patel Jamin (2017): In this research of comparative analysis of selected private and public sector bank in India, found that both nationalized and private sector banks are performing significantly from profitability perspective.

S. Kumar Jana \& A. Maiti (2017): In their research, the effectiveness of profitability ratios on productivity of banks are highly significant in selected banks both from public and private sector.

S. Waraic \& A. Kaur Sodhi (2016): In their research they focused on comparative analysis of efficiency measures taken by both public and private sector banks in India. They found that banks in private sector are performing better than the public sector banks. The only reason behind successful performance of banks in private sector is extend customer service. Hence, they suggested that banks in public sector must focus on customer service and management of good relations with customers.

Brajesh Kumar (2016): In his research, he made an assessment of employees working in commercial banks of both in India and Nepal. He found that the performance of a worker i.e. magnitude of sales by each employee are high in Nepal where as it is low in India.

A K Singh (2015): He has done the research on position of private banks in India from profitability perspective. The conclusion is, the performance of private banks is good in terms of quality of service compared to public sector banks. V. Rina \& Sommanek (2014): In his research on efficiency of workers in banking sector, found that the magnitude of sales by each employee is same both in selected banks from public and private sector. Even the value addition or contribution by each worker is also same.

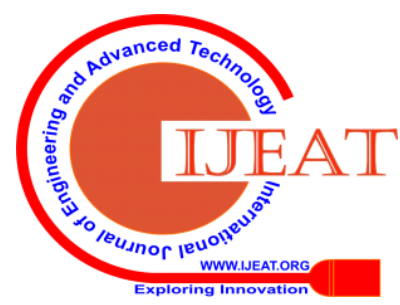


C. Rekhi Goel (2013): According to the research findings of this study, public sector banks are under performing in relation private sector banks in India.

The selected parameters for measuring the efficiency of banks are margin of interest rate, ROE and ROA.

Koundal Virender (2012): In his research on efficiency of banks and financial system in India found that foreign players and private banks are recording a standard growth rate in their operational efficiency compare to selected banks in public sector.

\section{CONCEPTUAL MODEL}

A structured model is utilized for the research is predominantly founded on the efficiency and performance from profitability perspective. There is a sure relationship among measures of efficiency and performance which ought to be deliberately dismembered and dissected, to get their comparing sway on gainfulness. In this way, it is important to raise the various suppositions of the explanatory structure. The magnitude of sales by each employee, value addition per representative, PBT per representative, Cost of Sales, Employee Cost to Value addition premium are chosen as measures to efficiency of banks. ROA, ROE and Value added to Fixed Assets are chosen as Profitability proportions of banks. The significant areas of efficiency and performance are depicted in the following diagram.

\section{Diagram-1: Conceptual Model Development}

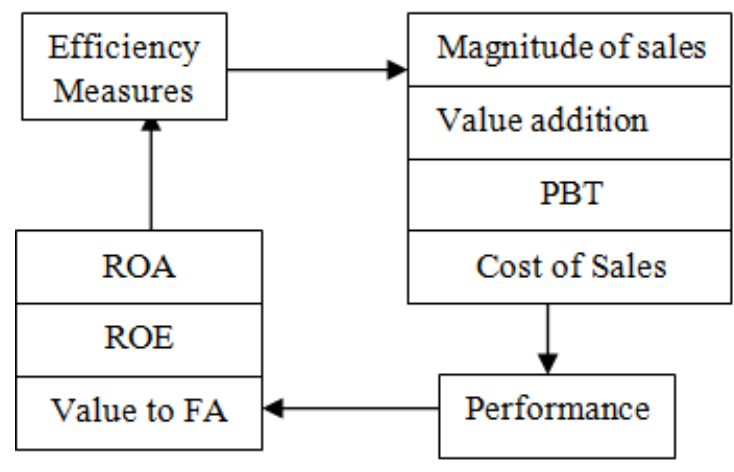

\section{OBJECTIVES}

1. To know the impact of efficiency measures on performance of banks selected both in private and public sector.

2. To evaluate the variables which influences the efficiency of banks selected both in private and public sector

3. To assess and compare the ratios of profitability of banks selected both in private and public sector

\section{METHODOLOGY}

The methodology must specify the methods of data collection and techniques used for analysis and also the frontiers of research work within which it has to be done. In

order to collect data for this research, non probability samplings methods are used especially judgemental sampling method. A blend of public and private sector banks (20) are selected for doing research. Out of which 10 banks are undertaken by Government and remaining 10 banks belongs to private sector working in India. The sample of banks is tabulated below (see table-1). The following financial parameters considered for evaluating the efficiency and yield of selected banks both in private and public sector viz., magnitude of sales per employee, value addition by worker, PBT, cost of sales, ROA, ROE and value addition to fixed assets. Simple Regression and multiple correlation analysis are used to analyse the collected data.

Table-1: Sample Size

\begin{tabular}{|l|l|}
\hline $\begin{array}{l}\text { Sl. } \\
\text { No. }\end{array}$ & Name of the Bank \\
\hline $\begin{array}{l}\text { Banks Under Public Sector } \\
\text { (Govt. of India Undertaking) }\end{array}$ \\
\hline $\mathbf{1}$ & Bank of Baroda(BOB) \\
\hline $\mathbf{2}$ & Bank of India(BOI) \\
\hline $\mathbf{3}$ & Central Bank of India(CBI) \\
\hline $\mathbf{4}$ & Oriental Bank of Commerce(OBC) \\
\hline $\mathbf{5}$ & State Bank of India (SBI) \\
\hline $\mathbf{6}$ & Syndicate Bank(SB) \\
\hline $\mathbf{7}$ & Andhra Bank(AB) \\
\hline $\mathbf{8}$ & Canara Bank(CB) \\
\hline $\mathbf{9}$ & Allahabad Bank(AB) \\
\hline $\mathbf{1 0}$ & Indian Bank(IB) \\
\hline Banks Under Private Sector \\
\hline $\mathbf{1 1}$ & Yes Bank(YB) \\
\hline $\mathbf{1 2}$ & Dhanalakshmi Bank(DB) \\
\hline $\mathbf{1 3}$ & Karur Vysya Bank(KVB) \\
\hline $\mathbf{1 4}$ & City Union Bank(CUB) \\
\hline $\mathbf{1 5}$ & Fedaral Bank(FB) \\
\hline $\mathbf{1 6}$ & South India Bank(SIB) \\
\hline $\mathbf{1 7}$ & Laxmi Vilas Bank(LVB) \\
\hline $\mathbf{1 8}$ & Karnataka Bank(KB) \\
\hline $\mathbf{1 9}$ & ICICI \\
\hline $\mathbf{2 0}$ & HDFC \\
\hline
\end{tabular}

\section{HYPOTHESES}

The following hypotheses are considered for testing under this research.

Null Hypothesis-1: The association between efficiency and profitability measures of banks selected both in private and public sector is nil or insignificant.

Null Hypothesis-2: The effectiveness of efficiency measures on yield of banks selected both in private and public sector is nil or insignificant.

Alternative to Null Hypothesis-1: The association between efficiency and profitability measures of banks selected both in private and public sector is positively significant.

Alternative to Null Hypothesis-2: The effectiveness of efficiency measures on yield of banks selected both in private and public sector is positively significant. 


\section{RESULTS ANALYSIS}

Table-2: Results of correlation analysis of selected banks (results @ 5\% level of significance)

\begin{tabular}{|l|l|l|l|l|l|l|l|}
\hline $\begin{array}{l}\text { Parameters } \\
\text { or } \\
\text { Ratios }\end{array}$ & $\begin{array}{l}\text { Magnitude } \\
\text { of } \\
\text { Sales per } \\
\text { worker }\end{array}$ & $\begin{array}{l}\text { Value } \\
\text { Addition } \\
\text { by } \\
\text { employee }\end{array}$ & $\begin{array}{l}\text { Profit } \\
\text { Before } \\
\text { Tax }\end{array}$ & $\begin{array}{l}\text { Cost } \\
\text { of } \\
\text { Sales }\end{array}$ & $\begin{array}{l}\text { Return } \\
\text { on } \\
\text { Assets }\end{array}$ & $\begin{array}{l}\text { Return } \\
\text { on } \\
\text { Equity }\end{array}$ & $\begin{array}{l}\text { Value } \\
\text { Addition to } \\
\text { Fixed } \\
\text { Assets }\end{array}$ \\
\hline Magnitude of Sales per worker & - & - & - & - & - & - & - \\
\hline Value addition by employee & 0.169 & - & - & - & - & - & - \\
\hline Profit Before Tax & 0.86 & -0.124 & - & - & - & - \\
\hline Cost of Sales (COS) & -0.419 & 0.24 & 0.28 & - & - & - & - \\
\hline Return on Assets & -0.488 & -0.159 & -0.172 & -0.185 & - & - & - \\
\hline Return on Equity & -0.499 & -0.568 & -0.432 & -0.582 & 0.147 & - \\
\hline Value Addition to Fixed Assets & -0.177 & -0.148 & -0.152 & -0.149 & -0.162 & -0.477 \\
\hline
\end{tabular}

Interpretation: From the table-2, it is clear that magnitude of sales per worker has a significantly positive relationship with cost of sales and return on assets as the multiple correlation coefficient values are negative compare to it $(-0.419$ and -0.488$)$. Similarly return on equity and value addition to fixed assets are also positively correlated as these variable values also less than the magnitude of sales per worker (-0.499 and -0.177). Likewise profit before tax is also associated positively with volume of sales per worker.

Table-3: Regression analysis results @ 5\% level of significance (public sector banks)

\begin{tabular}{|l|l|l|l|}
\hline Regression Analysis Statistic(s) & Return on Assets & Return on Equity & Value Addition to Fixed Assets \\
\hline Multiple Regression R value & 0.874 & 0.836 & 0.647 \\
\hline $\mathrm{R}^{2}$ value & 0.768 & 0.683 & 0.386 \\
\hline $\mathrm{R}^{2}$ value adjusted & 0.791 & 0.674 & 0.381 \\
\hline Standard Error & 0.00253 & 2.95348 & 1.09989 \\
\hline Number of Observations & 100 & 100 & 100 \\
\hline F value calculated & 68.146 & 39.421 & 31.986 \\
\hline P value calculated & 0 & 0 & 0 \\
\hline
\end{tabular}

Interpretation: From the table-3, it is clear that the adjusted $\mathrm{R}^{2}$ value is 0.768 it means $76.8 \%$ of variance is there between independent variables with dependent variable i.e. return on asset. Therefore it is concluded that the efficiency or yield of return on asset is significantly positive with magnitude of sales per worker and profit before tax. Similar analysis can be observed with return on equity and value addition to fixed assets.

Table-4: Regression analysis results @ 5\% level of significance (private sector banks)

\begin{tabular}{|l|l|l|l|}
\hline Regression Analysis Statistic(s) & Return on Assets & Return on Equity & Value Addition to Fixed Assets \\
\hline Multiple Regression R value & 0.937 & 0.827 & 0.825 \\
\hline $\mathrm{R}^{2}$ value & 0.872 & 0.674 & 0.659 \\
\hline $\mathrm{R}^{2}$ value adjusted & 0.864 & 0.56 & 0.638 \\
\hline Standard Error & 0.00247 & 2.84562 & 0.87648 \\
\hline Number of Observations & 100 & 100 & 100 \\
\hline F value calculated & 119.245 & 38.436 & 36.684 \\
\hline P value calculated & 0 & 0 & 0 \\
\hline
\end{tabular}

Interpretation: From the table-4, it is clear that the adjusted $\mathrm{R}^{2}$ value is 0.864 it means $86.4 \%$ of variance is there between independent variables with dependent variable i.e. return on asset. Therefore it is concluded that the efficiency or yield of return on asset is significantly positive with magnitude of sales per worker and profit before tax. Similar analysis can be observed with return on equity and value addition to fixed assets.

\section{CONCLUSION}

In the evaluation of performance of banks, one of the key parameter considered is efficiency measures. In this day and age banks are operating in the cutting edge competition market.There the measurement or evaluation of their performance in terms of efficiency rate is of more important and to bring it in reality various parameters including both independent and dependent are considered namely magnitude of sales per worker, cost of sales, value addition by each employee, Profit before tax, return on assets, return on equity and value addition to fixed assets. The results show that the efficiency of private sector banks is higher than the banks that are under taken by government of India. However, in few parameters like magnitude of sales per employee, cost of sales etc. banks under public sector are performing good compare to private sector banks. The reason behind this peculiar phenomena is that customers feel more secure about banks under public sector or under taken by government of India. But from the view point of return on assets, return on equity, value addition to fixed assets, banks under private sector are performing well.

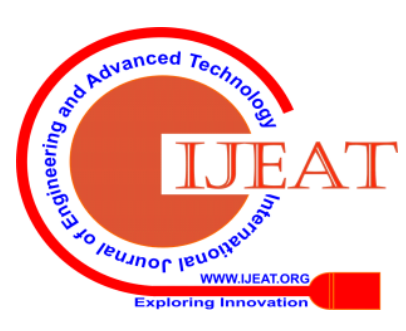


Despite of technical deficiencies, banks in public sector also offering customized services to the customers on par with private sector banks. Hence public sector banks also recording a remarkable growth from last couple of years.

\section{REFERENCES}

1. Jha, S., \& Hui, X. (2012). A comparison of financial performance of commercial banks: A case study of Nepal. African Journal of Business Management, 6(25), 7601-7611.

2. Chandan, C., \& Rajput, P. (2002). Profitability Analysis of Banks in India - A Multiple Regression Approach. Indian Management Studies Journal, 119-129.

3. Hassan, M., \& Bashir, A. (2003). Determinants of Islamic banking profitability. 10th ERF Annual Conference, (pp. 16-18).

4. Wasiuzzaman, S., \& Tarmizi, H. (2010). Profitability of Islamic banks in Malaysia: an empirical analysis. Journal of Islamic Economics, Banking and Finance, 6(4), 53-68.

5. Adwaita Maiti, \& Sebak Kumar Jana. (2017). Determinants of Profitability of Banks in India: A Panel Data Analysis. Scholars Journal of Economics, Business and Management, 4(7), 436-445.

6. Ahmed, Abdulkader Mohammed, Khababa, \& Nourredine. (1999). Performance of banking sector in Saudi Arabia. Journal of Financial Management and Analysis , 12(2), 30-36.

7. Alam, J., \& Riyadh, A. (2003, July-August). Measuring Productivity and Profitability of Banking in Bangladesh . Cost and Management.

8. Almazari, A. (2011). Financial performance evaluation of some selected Jordanian commercial banks. International Research Journal of Finance and Economics, 68(8), 50-63.

9. Amanjot Kaur Sodhi, \& Simran Waraich . (2016, January-February ). Fundamental Analysis of Selected Public and Private Sector Banks in India. NMIMS Management Review, 25(3)

10. Amit Kumar Singh. (2015). An analysis of profitability position of private bank in India. International Journal of Scientific and Research Publications, 5(5), 1-11.

\section{AUTHORS PROFILE}

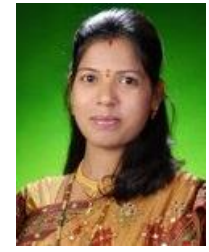

P. Sumalatha, Assistant Professor In Finance, Dr. B R Ambedkar Institute Of Management And Technology Hyderabad-44 E-Mail Id: Sumacmed@Gmail.Com Contact No.: +919247344928 